\title{
ANALISIS PERBEDAAN JIWA KEWIRAUSAHAAN MAHASISWA JURUSAN AKUNTANSI SYARIAH DAN EKONOMI SYARIAH
}

\author{
Amkhana Desyafitri \\ Muhammad Qoes Atieq \\ IAIN Syekh Nurjati Cirebon \\ muhammadqoesatieq@gmail.com
}

\begin{abstract}
Students in the millennial era have the business right now. Entrepreneurial spirit slowly grows in students. Not infrequently, many students study while doing entrepreneurship. The entrepreneurial spirit in this study refers to the explanation of the region. The entrepreneurial spirit that is owned by oneself consists of self-confidence, task-oriented, and outcome, dare to take risks, have leadership spirit, originality (authenticity) of business, and oriented into the future. The purpose of this study is to find out and explain the comparison of the entrepreneurial spirit in the department of sharia accounting and sharia economics. This type of research is a comparative descriptive study with a quantitative approach. Retrieving data using online questionnaires distributed to students majoring in accounting and economics sharia IAIN Sheikh Nurjati Cirebon. The sampling technique used is random sampling. A sample is used as much as 186 people from the respondents accounting majors sharia as much as 93 and majoring in islamic economics as much as 93. Whereas the data analysis uses descriptive analysis, inferential analysis, and independent sample T-test to compare. The results showed that there was no difference between the spirit of entrepreneurship in the department of sharia accounting and sharia economics.
\end{abstract}

Keywords : Entrepreneurship Spirit; Department of Sharia Accounting; Department of Sharia economics.

\section{PENDAHULUAN}

Produktivitas dapat meningkatkan kualitas hidup masyarakat terutama pada usia muda sehingga masyarakat pada usia tersebut harus memperhatikan hal tersebut (Tukiran, 2005). Berdasarkan pengamatan yang dilakukan pada lingkungan kampus menunjukkan bahwa ada sebagin besar mahasiswa yang menjalankan usahanya tapi tetap fokus juga pada perkuliahan (Aning et al., 2009). Salah satu faktor pendorong pertumbuhan kewirausahaan di suatu negara terletak pada peranan perguruan tinggi melalui pemberian pendidikan yang layak mengenai kewirausahaan kepada mahasiswanya, bukan hanya teori tetapi juga dengan praktek. Perguruan tinggi ini memiliki tanggung jawab dalam mendidik dan memberikan kemampuan wirausaha kepada para lulusannya serta memberikan motivasi untuk berani memilih berwirausaha sebagai karir setelah lulus nanti (Zimmerer, 2002).

Indonesia menghadapi masalah keterbatasan kesempatan kerja bagi para lulusan perguruan tinggi dengan semakin meningkatnya jumlah pengangguran terdidik belakangan ini. Berdasarkan laporan International Labor Organization (ILO) mencatat jumlah pengangguran terbuka pada tahun 2009 di Indonesia berjumlah 9,6 juta jiwa 
$(7,6 \%)$, dan $10 \%$ diantaranya adalah lulusan perguruan tinggi (Nasrun, 2010). Menurut data Badan Pusat Statistik terbaru pada tahun 2018, hampir 8\% dari total 7 juta lebih sarjana menganggur dan angka ini meningkat $1,13 \%$ dari tahun 2017. Namun menurut Kemenristek Dikti di tahun 2017 sarjana pengangguran mencapai $8,8 \%$ dan jumlahnya mencapai lebih dari 630 ribu orang (Ahmad et al., 2019). Program kewirausahaan juga mampu mengatasi permasalahan pengangguran terdidik dari kalangan mahasiswa pada masa sekarang. Program kewirausahaan yang dikemas dalam kegiatan kampus baik akademik maupun non akademik ini mampu menumbuhkan jiwa positif dan kuat bagi mahasiswa seperti tangguh, ulet, dan mandiri (Siswoyo, 2009).

Salah satu jurusan dengan prospek kerja yang sangat bagus adalah Akuntansi Syariah dan Ekonomi Syariah. Era modern sekarang, semua bidang industri atau perusahaan bahkan Usaha Mikro Kecil Menengah(UMKM) sangat membutuhkan lulusan dari sarjana akuntansi dan ekonomi untuk mengelola keuangan industri tersebut. Apabila spesifik pada jurusan Akuntansi Syariah dan Ekonomi Syariah, industri halal menjadi bagian penting dalam industri bisnis pada masa sekarang. Industri halal menjadi hal yang banyak dibicarakan oleh masyarakat dan juga menerapkannya. Terkait dengan prospek kerja yang bagus itu, banyak mahasiswa memilih untuk berkarir di suatu industri dan tidak memilih untuk menjadikan wirausaha sebagai karir mereka, padahal mereka telah dibekali ilmu kewirausahaan saat masih di bangku kuliah.

Kewirausahaan adalah kemampuan dalam menciptakan sesuatu yang baru dan berbeda (Kasmir, 2006). Artinya, wirausaha merupakan orang yang mampu menciptakan sesuatu (produk atau jasa) yang bermanfaat untuk dirinya sendiri dan orang lain serta berbeda dengan sesuatu yang sudah ada sebelumnya (Sirot, 2011). Wirausahawan adalah orangorang yang mampu menjawab tantangantantangan, melihat dan memanfaatkan peluangpeluang yang ada di dalam masyarakat untuk menciptakan tujuan sehingga meningkatkan kesejahteraan hidup diri sendiri maupun lingkungan yang Iebih luas (Dewanti, 2008).

Jiwa kewirausahaan adalah salah satu pendukung para pengusaha untuk meraih kesuksesan untuk usahanya di masa mendatang. Kegagalan atau keberhasilan wirausaha sangat dipengaruhi oleh sifat dan kepribadian seorang wirausaha itu sendiri (Suryana, 2006). Wirausahawan ini akan mendapat keberhasilan namun sangat bergantung pada jiwa kewirausahaan yang dimiliki oleh dirinya sendiri yang terdiri dari percaya diri, berorientasi pada tugas dan hasil, berani mengambil resiko, memiliki jiwa kepemimpinan, keorisinilan (keaslian) usaha, dan berorientasi ke masa depan (Meredith, 1992).

Perbedaan jiwa kewirausahaan diteliti karena masih banyak mahasiswa yang belum sepenuhnya memiliki jiwa kewirausahaan pada dirinya. Hal ini juga dilihat dari banyaknya sarjana perguruan tinggi yang memilih bekerja sebagai karyawan bukan sebagai wirausaha. Sama dengan pendapat bahwa pendidikan kewirausahaan belum mampu mengubah pemikiran lulusan perguruan tinggi dari diperkejakan menjadi yang mempekerjakan, dengan kata lain sebagai pencipta lapangan kerja. Walaupunmahasiswatelahmenyelesaikan mata kuliah kewirausahaan dalam satu semester bahkan kenyataannya sebagian besar lulusan masih berorientasi mencari pekerjaan dan mengalami masa tunggu kerja yang cukup lama (Handriani, 2011; Yuniza et al., 2012). Mahasiswa Akuntansi Syariah dan Ekonomi Syariah menjadi sampel dalam penelitian ini dikarenakan kedua jurusan itu memiliki profil lulusan sebagai entrepreneur, sehingga apabila dilakukan penelitian lebih umum. Akuntansi Syariah dan Ekonomi Syariah juga merupakan jurusan baru yang bisa menjadi objek penelitian dan dapat digunakan untuk melihat perkembangan mahasiswanya terkait dengan kewirausahaan.

Perkembangan jiwa kewirausahaan tidak terlepas dari jiwa dan pengalaman seseorang yang akan menjalankan usaha. Pengalaman awal dapat mempengaruhi kewirausahaan untuk kedepannya. Pengalaman awal ini akan 
berkaitan erat dengan sebuah keberhasilan yang hendak dicapai dan prestasi yang sangat berhubungan dengan jiwa kewirausahaan yang dimiliki pada masa depan (Obschonka, 2013).

Berdasarkan pendapat di atas dapat disimpulkan bahwa jiwa kewirausahaan pada mahasiswa harus benar-benar ditanamkan dengan baik sehingga ketika lulus nanti mahasiswa bukan hanya berkarir semata melainkan memilih wirausaha sebagai suatu pekerjaan yang akan dijalankan. Jiwa kewirausahaan yang dimiliki dapat mendorong usaha yang akan dijalankan. Maka, tujuan dari penelitian ini adalah untuk mengetahui perbandingan jiwa kewirausahaan mahasiswa Jurusan Akuntansi Syariah dan Ekonomi Syariah.

\section{REVIEW LITERATUR DAN HIPOTESIS}

\section{Landasan Teori}

\section{A. Jiwa Kewirausahaan}

Mahasiswa Jurusan Akuntansi Syariah dan Ekonomi Syariah pasti mendapatkan mata kuliah kewirausahaan saat dibangku perkuliahan. Mata kuliah kewirausahaan saat ini telah menjadi mata kuliah wajib di dalam perguruan tinggi. Pendidikan kewirausahaan yang diberikan tidak sekedar memberikan landasan teoritis mengenai bagaimana konsep kewirausahaan dan tetapi membentuk sikap, perilaku, dan mindset seorang wirausahawan yang baik (Retno, 2012). Perguruan tinggi dalam menciptakan wirausaha baru sangat bergantung pada proses pendidikan kewirausahaan yang diberikan oleh para dosen di bangku kuliah. Nampaknya selama ini pendidikan kewirausahaan dilaksanakan dengan bobot 2-3 sks pada satu atau dua semester. Pada Jurusan Akuntansi Syariah dan Ekonomi Syariah mata kuliah kewirausahaan mempunyai bobot 2 sks. Padahal menumbuhkan jiwa kewirausahaan pada diri mahasiswa bahkan sampai mahasiswa tersebut menjadi wirausaha itu harus dilakukan secara bertahap dan terus menerus selama mereka belajar di dalam kampus (Murtini, 2008).

Wirausaha adalah orang yang berjiwa kreatif dan inovatif yang mampu mendirikan, membangun, mengembangkan, memajukan, dan menjadikan perusahaannya unggul (Eddy, 2009). Entrepreneur merupakan seseorang yang mampu atau sedang menciptakan sebuah usaha yang diharapkan dengan ketidakpastian serta risiko untuk mendapatkan keuntungan dan mengembangkan bisnis dengan cara membuka lapangan kerja bagi orang lain (Sumardi, 2007). Jiwa kewirausahaan adalah nadi kehidupan di dalam kewirausahaan. Pada prinsipnya sikap dan perilaku kewirausahaan dengan ini ditunjukkan dengan sifat, karakter, dan watak seseorang yang memiliki kemauan lebih dalam mewujudkan ide serta gagasan yang inovatif dan kreatif ke dalam dunia nyata (Hartanti, 2008). Entrepreneurship merujuk kepada jiwa kewirausahaan yang hampir disamakan pada sifat-sifat atau karakter psikologis yang harus dimiliki oleh seorang wirausahawan (Helmi, 2009).

Menurut Suryana (2006) seorang yang mempunyai jiwa kewirausahaan haruslah memiliki ciri-ciri sebagai berikut:

1. Sangat percaya diri misalnya berkeyakinan penuh terhadap hasil yang telah diciptakan olehnya, memiliki jiwa optimis tinggi, disiplin termasuk mengenai waktu dalam menciptakan produk, bertanggung jawab penuh terhadap segala hal yang berkaitan dengan usahanya.

2. Memiliki inisiatif yang indikatornya adalah penuh energi, cekatan dalam bertindak dalam artian tidak membuang-buang waktu, dan aktif.

3. Memiliki motif berprestasi yang indikatornya adalah berorientasi 
pada hasil yang akan diciptakan dan berwawasan luas.

4. Memiliki jiwa kepemimpinan yaitu mampu berkerja sama dengan tim, berani tampil beda, dapat dipercaya, berhati-hati dalam mengambil keputusan.

5. Berani mengambil risiko yang indikatornya adalah penuh perhitungan dalam mengambil keputusan.

Jadi, pemberian materi mengenai kewirausahaan dapat membentuk perilaku, cara berfikir serta sikap pada mahasiswa untuk menjadi seorang entrepreneur sehingga dapat mengarahkan mahasiswa untuk memilih berwirausaha sebagai karir mereka setelah lulus dari program sarjana yang ditempuh.

Salah satu komponen pembangunan bangsa yang sangat potensial adalah mahasiswa. Dengan rentang usia yang tergolong masih muda, tenaga yang energik, jaringan yang cukup luas mampu berkreativitas tinggi menjadi sebuah pondasi dan modal dasar bagi kemajuan negara (Heri, 2018). Mahasiswa merupakan makhluk sosial dan juga makhluk individu, mahasiswa tidak bisa hidup sendiri, mereka hidup berdampingan ataupun selalu membutuhkan orang lain dalam memenuhi kebutuhannya, oleh karena itu mahasiswa disebut sebagai makhluk sosial. Sebagai makhluk individu juga mahasiswa mempunyai kebutuhan-kebutuhan yang berbeda antara satu individu dengan individu lainnya (Wenny, 2018). Pendapat yang sama bahwa mahasiswa sebagai individu yang sedang menimba ilmu di tingkat perguruan tinggi, baik negeri maupun swasta atau lembaga lain setara seperti perguruan tinggi. Mahasiswa dianggap memiliki tingkat intelektualitas yang tinggi, kecerdasan dalam berpikir, berpendapat, serta penuh pertimbangan dalam mengambil keputusan atau bertindak (Siswoyo, 2007).

Terealisasinya sebuah usaha kecil didasari oleh terdapatnya jiwa kewirausahaan yang merupakan kepribadian dan telah terinternalisasi melalui nilai-nilai kewirausahaan khususnya untuk orang yang melakukan suatu usaha. Jiwa kewirausahaan yang tinggi diperlukan dalam menciptakan kemandirian usaha bagi pelaku usaha kecil (Sukirman, 2017). Seiring dengan banyaknya mahasiswa yang tidak hanya berkuliah saja namun banyak yang melakukan wirausaha, jiwa kewirausahaan ini akan menjadi penting bagi mereka karena dengan adanya jiwa kewirausahaan yang telah melekat dapat menciptakan kemandirian pada usahanya dan dirinya.

\section{Hipotesis}

1. Perbedaan Signifikan Jiwa Kewirausahaan antara Mahasiswa Jurusan Akuntansi Syariah dan Mahasiwa Jurusan Ekonomi Syariah

Penelitian ini bertujuan untuk mengetahui perbandingan jiwa kewirausahaan mahasiswa Akuntansi Syariah dan Ekonomi Syariah. Penelitianpenelitian sebelumnya tentang jiwa kewirausahaan cenderung lebih pada melihat jiwa kewirausahaan mahasiswa, bukan membandingkan tingkat jiwa kewirausahaan mahasiswa. Pada penelitian ini lebih menitikberatkan pada antar jurusan dikarenakan selain jurusan baru sebagai peningkatan mahasiswanya, berdasarkan observasi yang dilakukan ditemukan bahwasanya kedua jurusan tersebut sedikit yang berwirausaha. Hal tersebut menunjukkan bahwasanya sebagai jurusan yang mempunyai profil lulusan sebagai entrepreneur hanya sedikit yang berwirausaha.

Penelitian sebelumnya tersebut bisa dijadikan referensi dalam melihat jiwa kewirausahaan mahasiswa. Pada penelitian yang dilakukan oleh Nugroho (2012) jiwa kewirausahaan mahasiswa Universitas Trunojoyo Madura mempunyai jiwa kewirausahaan yang tinggi dengan ditunjukkan pada karakteristik yang berorientasi jangka panjang pada mahasiswa. Mahasiswa lebih melihat faktor di masa depan untuk memulai berwirausaha. Penelitian yang dilakukan oleh Krisnaresanti, dkk (2018) menunjukkan bahwasanya 
mahasiswa akuntansi mempunyai jiwa kewirausahaan yang tinggi pada karakteristik yang berorientasi pada hasil. Hal tersebut menunjukkan bahwasanya mahasiswa ingin beriwirausaha karena melihat hasil yang didapatkan sangat menguntungkan. Penelitian lain yang dilakukan oleh Endratno \& Widhiandhono (2014) tentang intensi kewirausahaan mahasiswa yang membandingkan antara mahasiswa Fakultas Ekonomi Universitas Muhammadiyah Purwokerto dan mahasiswa Fakultas Ekonomi Universitas Jenderal Soedirman menunjukkan bahwasanya tidak adanya perbedaan intensi kewirausahaan antara kedua kelompok mahasiswa pada fakultas tersebut. Dari uraian tersebut, maka hipotesis penelitian ini adalah:

H1: Terdapat Perbedaan Jiwa Kewirausahaan yang Signifikan antara Mahasiswa Jurusan Akuntansi Syariah dan Mahasiswa Jurusan Ekonomi Syariah

\section{METODE PENELITIAN}

Metodologi penelitian yang digunakan dalam penelitian ini adalah penelitian deskriptif komparatif dengan pendekatan kuantitatif dan survei menggunakan kuesioner. Berdasarkan penjelasan Cooper (2014) penelitian komparatif ini membandingkan satu variabel dengan beberapa sampel yang berbeda yaitu antara jiwa kewirausahaan pada Jurusan Akuntansi Syariah dan Ekonomi Syariah.

Proses pengukuran jiwa kewirausahaan mahasiswa Akuntansi Syariah dan Ekonomi Syariah dengan menggunakan alat ukur berupa kuesioner, yang diambil dari teori Meredith (1992). Teknik Sampling yang digunakan dalam penelitian ini yaitu random sampling. Pengambilan data dilakukan dengan cara menggunakan kuesioner melalui google form yang disebarkan secara online ke beberapa mahasiswa Jurusan Akuntansi Syariah dan Ekonomi Syariah dari tanggal 12 Mei 2020 sampai dengan 24 Mei 2020 dengan responden mahasiswa Jurusan Akuntansi Syariah dan Ekonomi Syariah. Analisis pada penelitian ini menggunakan SPSS 22. Responden yang didapat dari proses penyebaran kuesioner adalah sebanyak 207 responden. Responden tersebut apabila dibagi secara jurusan yaitu Jurusan Akuntansi Syariah sebanyak 114 orang dan Ekonomi Syariah sebanyak 93 orang. Data yang digunakan dalam penelitian ini yaitu membandingkan responden mahasiswa Jurusan Akuntansi Syariah 93 orang dan Ekonomi Syariah 93 orang.

Menurut Cooper (2014) teknik analisis data yang akan digunakan adalah dengan menggunakan uji validitas dan realibilitas dari alat ukur yang digunakan dengan metode membandingkan $r_{\text {tabel }}$ dan $r_{\text {hitung, }}$, sedangkan uji realibilitas dengan menggunakan metode melihat nilai cronbach's alpha-nya. Alat ukur Jiwa kewirausahaan mahasiswa dengan menyebarkan kuesioner sesuai dengan teori yang dijelaskan oleh Meredith (1992). Teknik lain yang digunakan dalam analisis data yaitu dengan menggunakan analisis inferensial yaitu uji normalitas dengan menggunakan metode statistik Kolmogorov-Smirnov dan uji homogenitas menggunakan metode statistik Levene's Test for Equality of Variance. Analisis untuk menguji hipotesinya yaitu menggunakan uji analisis independent sample t-test.

\section{HASIL PENELITIAN DAN PEMBAHASAN}

\section{Uji Kualitas Alat Ukur}

Uji validitas dilakukan dengan membandingkan antara nilai $r_{\text {hitung }}$ dengan $r_{\text {tabel}}$, apabila $r_{\text {hitung }}$ lebih besar daripada $r_{\text {tabel }}$ nya, maka butir-butir pertanyaan dalam penelitian ini dinyatakan valid (Cooper, 2014). Berdasarkan perhitungan dengan menggunakan SPSS 22 butir-butir pertanyaan yang digunakan dalam penelitian ini adalah valid sehingga dapat digunakan sebagai alat ukur penelitian. 
Tabel 4.1

Hasil Uji Validitas

\begin{tabular}{|c|c|c|c|c|c|}
\hline Variabel & Nilai R hitung & Variabel & Nilai R Ritung & Variabel & Nilai R Ritumg \\
\hline 01 & 1 & 08 & 0.411 & 015 & 0.297 \\
\hline 02 & 0.458 & 09 & 0.624 & 016 & 0.489 \\
\hline 03 & 0.304 & 010 & 0.401 & 017 & 0.557 \\
\hline 04 & 0.382 & 011 & 0.379 & 018 & 0.316 \\
\hline 05 & 0.425 & 012 & 0.529 & 019 & 0.385 \\
\hline 06 & 0.363 & 013 & 0.562 & 020 & 0.757 \\
\hline 07 & 0.319 & 014 & 0.193 & \multicolumn{3}{|c}{} \\
\cline { 1 - 4 } & & &
\end{tabular}

Berdasarkan tabel 4.1 di atas menunjukkan bahwasanya $r_{\text {hitung }}$ lebih besar dari $r_{\text {tabel }}$ sebesar 0,168 , sehingga butir pertanyaan dapat disimpulkan valid. Sedangkan untuk menguji konsistensi jawaban atau realibilitasnya ditunjukkan oleh tingginya cronbach's alpha, dengan nilai alpha harus lebih besar dari 0,7 meskipun nilai 0,6 masih dapat diterima (Hair et al., 2006). Ringkasan hasil perhitungan uji reliabilitas dapat ditunjukkan pada tabel 4.2

Tabel 4.2

Hasil Uji Reliabilitas

\begin{tabular}{|c|c|c|}
\hline Variabel & $\begin{array}{c}\text { Koefisien } \\
\text { Cronbach's } \\
\text { Alpha }\end{array}$ & Keterangan \\
\hline $\begin{array}{c}\text { Jiwa } \\
\text { Kewirausahaan }\end{array}$ & 0,915 & Reliabel \\
\hline
\end{tabular}

\section{Uji Normalitas}

Pada penelitian ini uji normalitas digunakan untuk menguji apakah data penelitian yang diperoleh itu berdistribusi normal atau tidak. Teknik statistiknya dengan menggunakan statistik Kolmogorov-Smirnov karena sampel yang digunakan sebanyak 186 orang responden (Gujarati, 2012). Kriteria yang digunakan dalam uji normalitas ini adalah dengan cara membandingkan antara tingkat signifikansi yang didapat dengan tingkat alpha yang digunakan, dimana data tersebut dikatakan normal apabila nilai signifikansi > alpha (Cooper, 2014).
Tabel 4.3

Hasil Uji Normalitas

\begin{tabular}{|c|c|c|}
\hline \multirow{2}{*}{ Variabel } & \multicolumn{2}{|c|}{ Tingkat Signifikansi } \\
\cline { 2 - 3 } & $\begin{array}{c}\text { Akuntansi } \\
\text { Syariah }\end{array}$ & $\begin{array}{c}\text { Ekonomi } \\
\text { Syariah }\end{array}$ \\
\hline $\begin{array}{c}\text { Jiwa } \\
\text { Kewirausahaan }\end{array}$ & 0,113 & 0,102 \\
\hline $\begin{array}{c}\text { Jenis Distribusi } \\
\text { Data }\end{array}$ & Normal & Normal \\
\hline
\end{tabular}

Berdasarkan tabel 4.3 di atas uji normalitas data Kolmogorov-Smirnov menunjukkan nilai tingkat signifikansi lebih dari 0,05. Dapat dilihat pada Akuntansi Syariah hasilnya 0,113 lebih dari 0,05 dan data Ekonomi Syariah sebesar 0,102 lebih dari 0,05. Sehingga keseluruhan data bisa dikatakan berdistribusi normal.

\section{Uji Homogenitas}

Uji homogenitas digunakan untuk menguji data dalam penelitian ini homogen atau tidak, ketika data homogen maka akan dapat dilanjukan dengan uji selanjutnya yaitu uji independent sample t-test. Uji homogenitas di sini menggunakan levene's test for equality of variances, dan hasilnya sebagai berikut:

Tabel 4.4

Hasil Uji Homogenitas

\begin{tabular}{|c|c|c|}
\hline Variabel & Signifikan & Keterangan \\
\hline Jiwa & 0.914 & $\begin{array}{c}>0.05 \\
\text { Hipotesis } \\
\text { Kitolak }\end{array}$ \\
\hline
\end{tabular}

Berdasarkan hasil di atas menunjukkan bahwasanya nilai signifikansi sebasar 0,996 lebih besar dari taraf signifikansi sebesar 0,05 , sehingga menunjukkan bahwa data dalam penelitian ini adalah homogen atau varians datanya sama.

\section{Independent Sample T-Test}

Setelah diketahui bahwa data berdistribusi normal dan datanya juga bersifat homogen maka uji selanjutnya adalah independent sample t-test untuk membandingkan jiwa kewirausahaan mahasiswa Jurusan Akuntansi Syariah dan Ekonomi Syariah, dengan hasil sebagai berikut: 
Tabel 4.5

Hasil Independent Sample T-Test

\begin{tabular}{|c|c|c|}
\hline Variabel & $\begin{array}{c}\text { Signifik } \\
\text { an }\end{array}$ & $\begin{array}{c}\text { Keterang } \\
\text { an }\end{array}$ \\
\hline $\begin{array}{c}\text { Jiwa } \\
\text { Kewirausahaan }\end{array}$ & 0.996 & Homogen \\
\hline
\end{tabular}

Berdasarkan hasil uji anova di atas dengan menggunakan SPSS 22, menunjukkan tingkat signifikansi 0,914 . Untuk mengetahui apakah ada perbedaan jiwa kewirausahaan pada Jurusan Akuntansi Syariah dan Ekonomi Syariah, dengan cara membandingkan nilai signifikansi dengan taraf signifikasi (Sig. < 0.05). Hasil pada tabel 4.5 di atas menunjukkan bahwasanya nilai signifikansi lebih besar dari taraf signifikansi sebesar 0,05 , sehingga dapat disimpulkan tidak terdapat perbedaan dari jiwa kewirausahaan pada Jurusan Akuntansi Syariah dan Ekonomi Syariah. Berdasarkan hasil tersebut maka bisa disimpulkan hipotesis pada penelitian ini ditolak.

\section{Pembahasan}

Hipotesis dalam penelitian ini ditolak karena tidak ada perbedaan jiwa kewirausahaan mahasiswa Jurusan Akuntansi Syariah dan Ekonomi Syariah. Banyak faktor yang menyebabkan tertolaknya hipotesis. Yang pertama, dasar keilmuan yang sama antara mahasiswa Jurusan Akuntansi Syariah dan Ekonomi Syariah yang berlatar belakang ekonomi, mengakibatkan hasil dari uji analisis bisa dikatakan sama. Hal tersebut membuat tidak adanya perbedaan yang tingkat jiwa kewirausahaan antar mahasiswa tersebut. Berbeda ketika responden yang diteliti yaitu dari Jurusan Hukum Tata Negara atau Hukum Ekonomi Syariah, bisa jadi nanti hasilnya akan terdapat perbedaan. Hal tersebut dikarenakan memang lulusan dari jurusan hukum tersebut lebih mengarah pada bidang hukum bukan bisnis sehingga bisa dikatakan faktor karakteristik responden lemah terkait dengan jurusan dan lulusan masing-masing jurusan. Faktor lain dikarenakan memang basic mahasiswa Akuntansi Syariah dan Ekonomi Syariah diantaranya adalah bisnis, materi yang dipelajari dan standar materi kewirausahaan di IAIN Syekh Nurjati juga sama. Hal tersebut membuat tingkat jiwa kewirausahaan dari masing-masing mahasiswa antar jurusan sama. Hal tersebut menjelaskan bahwa mereka memiliki intensi, perhatian, dan semangat berwirausaha yang sama.

Perguruan tinggi sebagai lembaga pendidikan formal dalam hal ini diharapkan menghasilkan tenaga terdidik bahkan terampil. Pendidikan kewirausahaan yang diberikan oleh masing-masing perguruan tinggi berperan dalam memberikan pondasi pola fikir mahasiswa untuk mampu mengoptimalkan potensi yang ada dalam dirinya maupun lingkungan yang ada disekitarnya. Peran perguruan tinggi dalam mengembangkan kemampuan mahasiswa dalam berwirausaha diantaranya memupuk kemampuan mahasiswa dalam melihat kesempatan usaha, mengelola usaha serta memberikan motivasi keberanian mental yang kuat dalam menghadapi segala risiko dari usaha tersebut. Pembinaan mental kewirausahaan di lingkungan perguruan tinggi melalui pendidikan kewirausahaan diharapkan menjadi suatu cara yang ditempuh untuk menyatupadukan antara penguasaan ilmu dan teknologi dengan jiwa kewirausahaan mahasiswanya (Eriawaty, 2016). Pendidikan kewirausahaan di Perguruan Tinggi bukan semata-mata berarti pendidikan untuk menghasilkan sebuah usaha (bisnis), tapi harus diartikan sebagai pendidikan untuk membangun karakter wirausaha, pola pikir wirausaha, dan perilaku wirausaha bahkan jiwa berwirausaha mahasiswanya (Susilaningsih, 2015).

Perguruan tinggi dalamhal inimemberikan kesempatan untuk mahasiswa yang memang sudah berwirausaha maupun belum agar tetap belajar kewirausahaan, disamping pemberian mata kuliah kewirausahaan wajib bagi setiap jurusan, perguruan tinggi juga sekarang telah banyak membuka Unit Kegiatan Mahasiswa (UKM). IAIN Syekh Nurjati sendiri telah ada UKM yang siap mewadahi mahasiswamahasiswa yang ingin belajar berwirausaha yaitu ada Senjapreneur dan Koperasi Mahasiswa (KOPMA). Di UKM tersebut mahasiswa tidak hanya diajarkan mengenai 
materi kewirausahaan ataupun cara menjadi wirausaha dengan baik melainkan dipupuk dan dibekali mental berwirausaha. UKM tersebut dilihat sangat aktif dalam mengadakan eventevent mengenai kewirausahan dan sering kali mengadakan pelatihan bahkan seminar yang mengundang pemateri wirausahawan sukses baik dari dalam maupun dari luar kampus. Tidak hanya sebatas UKM saja, namun banyak Himpunan Mahasiswa Jurusan yang memiliki departemen atau divisi kewirausahaan di organisasinya. Hal ini dilakukan juga untuk mengembangkan jiwa kewirausahaan pada para anggotanya selain itu juga untuk menambah dana dalam mengadakan sebuah kegiatan yang membutuhkan dana cukup besar tentunya.

Perguruan tinggi khususnya para dosen pengampu mata kuliah kewirausaan diharapkan tidak hanya memberikan teori saja melainkan prakteknya dilapangkan. Contohnya seperti mahasiswa dibentuk beberapa kelompok dalam satu kelas untuk menjual beberapa produk buatan sendiri (handmade) maupun produk orang lain. Hal ini dilakukan guna melatih mental berwirausaha serta memperkenalkan dunia usaha. Profil Jurusan Akuntansi dan Ekonomi sangat menjanjikan ketika lulus nanti karena semua sektor membutuhkan lulusan di bidang ekonomi terutama akuntansi. Namun, di era sekarang semakin banyaknya perguruan tinggi baik negeri maupun swasta yang membuka Jurusan Akuntansi dan Ekonomi membuat lulusannya tidak bekerja pada bidangnya, melainkan banyak menjadi wirausahawan.

Generasi sekarang adalah generasi yang memiliki jiwa kewirausahaan yang tinggi dilihat dari banyaknya anak-anak muda yang sudah mulai berusaha sejak dini dan juga ada banyak yang ingin berusaha sendiri, namun belum berani untuk mencoba saja. Mereka berlatih dengan menjadi reseller produk orang. Kemudian setelah mereka sudah menguasai ilmunya perlahan-lahan mereka membuka usaha sendiri sesuai dengan minatnya. Selama menjalankan usaha, mahasiswa memperoleh banyak pengalaman yang berharga. Jiwa kewirausahaan yang berkembang diantaranya kemampuan mengelola tim (teamwork), menjadi pribadi yang lebih kreatif dan inovatif serta menjadi lebih kuat dalam menerima risiko (Heri, 2018). Jiwa kewirausahaan tumbuh karena ada kemauan yang besar dan pantang menyerah dari diri sendiri. Alasan berwirausaha juga berbeda antara setiap mahasiswa, mereka rata-rata berfikir bahwa mengandalkan uang saku dari orang tua tidak akan cukup untuk memenuhi keinginan mereka apalagi posisi mereka ada di perantauan yang jauh dari rumah, malu jika harus terus menerus meminta.

Saat ini pendidikan kewirausahaan sudah diterapkan dan dikembangkan hampir di semua perguruan tinggi di Indonesia dengan proses pembelajaran yang bervariasi dengan tujuan untuk menciptakan wirausaha (Susilaningsih, 2015). Dengan mata kuliah kewirausahaan yang dibarengi dengan praktik, mahasiswa tidak hanya pintar akademik saja, melainkan mereka mempunyai keterampilan dalam memimpin, bekerja sama dalam team, memiliki mental yang kuat, berpikir kreatif dan inovatif, dan memiliki daya saing yang tinggi. Kewirausahaan merupakan program yang sangat dibutuhkan dan diperlukan guna melahirkan generasi masa depan yang berkualitas dan mampu menghadapi perubahan zaman (Heri, 2018).

\section{KESIMPULAN DAN SARAN}

\section{Kesimpulan}

Berdasarkan hasil penelitian di atas, maka dapat disimpulkan bahwa:

1. Tidak terdapat perbedaan antara jiwa kewirausahaan pada Jurusan Akuntansi Syariah dan Ekonomi Syariah. Hasil tersebut dilihat dari nilai signifikansi lebih besar dari taraf signifikansi $(0,914>0,05)$. Artinya, mahasiswa Jurusan Akuntansi Syariah dan Ekonomi Syariah mempunyai tingkat jiwa kewirausahaan yang sama. Kesamaan jiwa kewirausahaan Jurusan Akuntansi Syariah dan Ekonomi Syariah karena memang pemberian mata kuliah pada masing-masing jurusan itu setara. 
Jadi jiwa kewirausahaan mahasiswa Jurusan Akuntansi Syariah dan Ekonomi Syariah pun sama.

\section{Saran}

Saran yang dapat diberikan dalam penelitian ini di antaranya:

1. Saran untuk penelitian selanjutnya yang terkait dengan jiwa kewirausahaan lebih banyak lagi untuk sampel penelitian karena untuk melihat hasil yang lebih akurat dan juga jelas. Responden yang diteliti harus dengan jurusan yang berbeda. Terkait dengan variabel jiwa kewirausahaan, selanjutnya lebih menggabungkan dengan variabel-variabel yang lainnya sehingga lebih rinci hasil dan pembahasannya. Objek penelitian yang digunakan bisa lebih bervariatif.

\section{DAFTAR PUSTAKA}

Aning, A. Z. et al., (2019). Dinamika Pengambilan Keputusan dan Perkembangan Jiwa Wirausaha pada Mahasiswa. Psympathic: Jurnal Ilmiah Psikologi. Volume 6, Nomor 1.

Ahmad R. A. et al., (2019). Pengaruh Pendidikan Kewirausahaan dan Dukungan Akademik terhadap Niat Kewirausahaan Mahasiswa. Jurnal Kajian Ilmiah. Volume 19, No. 2.

Cooper, D.R. dan Schindler, P.S. (2014). Business Research Methods, 12th ed., New York: Irwin/McGraw-Hill.

Dewanti. (2008). Kewirausahaan. Jakarta: Mitra Wacana Media.

Endratno, H. dan Widhiandhono, H., (2014). Intensi Kewirausahaan Mahasiswa (Studi Perbandingan antara Mahasiswa FE UMP dan FE UNSOED). Seminar Nasional dan Call for Paper
Sustainable Competitive Advantage (SCA) Purwokerto.

Eriawaty dan Fitriyati.(2016).Peran Mata Kuliah Kewirausahaan dalam Menumbuhkan Jiwa Wirausaha Mahasiswa Pendidikan Ekonomi. Jurnal Profit, Volume 3, Nomor 1.

Gujarati, D. N. (2013). Dasar-Dasar Ekonometrika, Edisi Kelima. Mangunsong, R. C. penerjemah. Jakarta: Salemba Empat.

Hartanti. (2008). Manajemen Pengembangan Kewirausahaan (Enterpreneurship) Siswa SMK 4 Yogyakarta. Tesis Tidak Dipublikasikan. Universitas Negeri Yogyakarta.

Hair, J. F. et al., (2006). Multivariate Data Analysis. Fifth Edition. Jakarta: Gramedia Pustaka Utama.

Handriani, Eka. (2011). Pengembangan Kualitas Pendidikan Kewirausahaan di Perguruan Tinggi. Jurnal Ilmiah Inkoma, Volume 22, No.1, pp.83-95.

Helmi, A. F. (2009). Kewirausahaan di Perguruan Tinggi dalam Perspektif Psikologi. Buletin Psikologi, 17(2), 5765. doi.org/10.22146/bpsi.11483.

Heri, M. (2018). Pengembangan Jiwa Kewirausahaan: Studi Kasus terhadap Mahasiswa yang Berwirausaha di Yogyakarta. Jurnal Ecodemica, Vol. 2 No. 1.

Kasmir. (2007) Kewirausahaan. Jakarta: PT Raja Grafindo Perkasa.

Krisnaresanti, A., Dkk. (2018). Analisis Jiwa Kewirausahaan Mahasiswa D3 Akuntansi Universitas Jenderal Soedirman. Seminar Nasional dan Call for Paper Sustainable Competitive Advantage (SCA) 8 Purwokerto. 
Meredith, Geoffrey G. (1992). Kewirausahaan Teori dan Praktek. Jakarta: PT Pustaka Binaman Pressindo.

Murtini, Wiedy. (2008). Success Story sebagai Pendekatan Pembelajaran Kewirausahaan. Varia Pendidikan, Volume 20, No.2, pp.173183.

Nasrun, M. A. (2010). Mengapa Banyak Sarjana yang Menganggur?. Suara Merdeka.

Obschonka, M., Andersson, H., Silbereisen, R. K., \& Sverke, M. (2013). Rule Breaking, Crime, and Entrepreneurship: A Replication and Extension Study with 37-Year Longitudinal Data. Journal of Vocational Behavior, 83(3), 386-396. doi.org/10.1016/j.jvb.2013.06.007.

Retno, B. L dan Trisnadi, Wijaya. (2012) Pengaruh Pendidikan Kewirausahaan terhadap Minat Berwirausaha Mahasiswa di STIE MDP, STMIK MDP, dan STIE MUSI. Jurnal Ilmiah STIE MDP. Vol. 1 No. 2 Maret 2012. Hal 112.

Siswoyo, Bambang, B. (2009). Pengembangan Jiwa Kewirausahaan di Kalangan Dosen dan Mahasiswa. Jurnal Ekonomi Bisnis, Fakultas Ekonomi Universitas Negeri Malang. 14 (2): 114-23.

Sirot, Irjianto. (2011). Kewirausahawanan dan Karakteristik Individu Wirausaha Rambak di Desa Bangsal Mojokerto. Jurnal Manajemen Bisnis, Vol 1 No 2. Hal. 145.

Soegoto, E. S. (2009). Entrepreneurship Menjadi Pebisnis Ulung. Elex Media Computindo
Sukirman. (2017). Jiwa Kewirausahaan dan Nilai Kewirausahaan Meningkatkan Kemandirian Usaha melalui Perilaku Kewirausahaan. Jurnal Ekonomi dan Bisnis, Volume 20, Nomor 1.

Suryana. (2006). Kewirausahaan: Pedoman Praktis Kiat dan Proses Menuju Sukses. Jakarta: Salemba Empat.

Susilaningsih. (2015). Pendidikan Kewirausahaan di Perguruan Tinggi: Pentingkah untuk Semua Profesi?. Jurnal Economia, Volume 11, Nomor 1.

Tukiran dan Mustar Endang Ediastuti. (2005). Dinamika Pengangguran di Daerah Istimewa Yogyakarta. Jurnal Populasi, Yogyakarta, Pusat Studi Kependudukan dan Kebijakan UGM.

Wenny, H dan Rizki, M. D. (2018). Analisis Tugas Perkembangan Mahasiswa Fakultas Ilmu Pendidikan Universitas Negeri Gorontalo. Jurnal Bikotetik. Volume 02 Nomor 0.

Yuniza, Ahadiah., Tanjung, Hery Bachrizal., dan Adrizal. (2012). Peningkatan Mutu Pembelajaran Kewirausahaan pada Fakultas Pertanian dan Peternakan Universitas Andalas. http://repository. unand.ac.id/3340/2/AHADIY AH_Y. pdf, diakses pada 21/12/2012.

Zimmerer, W.T. (2002). Essentials of Entrepreneurship and Small Business Management. Third Edition. New York: Prentice-Hall. 